\title{
Exploring possibilities of social entrepreneurial activities as a tool to reduce unemployment amongst churches in Tshwane central and Mamelodi East: Pretoria case study
}

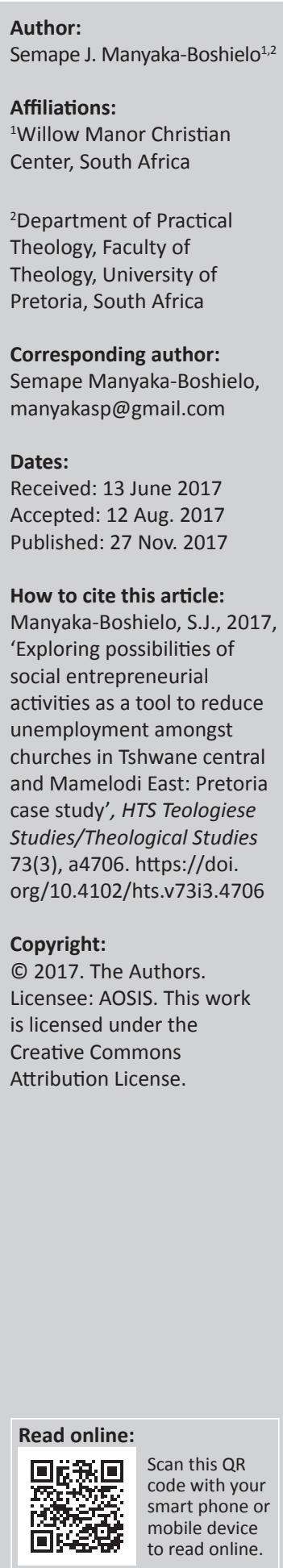

Unemployment is one of the major problems in South Africa. It is the concern of the government and the people at large to engage in means in order to reduce poverty. In this research, I would like to explore the possibilities of social entrepreneurial activities as a way of social and economic transformation in Tshwane. If this could be a possibility it means the church can go all out to see that the communities and members are encouraged to engage in. People will be able to improve their lives without depending on the grants from the government. Our methodology will be a literature review and intra-disciplinary approach. The method would be community mapping, World Café and focused group.

\section{Introduction}

Listening to the stories of research participants, it is not surprising that they mention that unemployment is one of the major challenges people are facing in Mamelodi and the inner city of Pretoria. This is in congruence with the general statistics of South Africa.

South Africa has been described as having a high level of poverty and this is unacceptable; youth unemployment in particular is excessive (Manyaka 2014:4).

In 2015, 3.6 million young people (between $35.0 \%$ and $37.0 \%$ of this demographic) were reported unemployed and were actively looking for a job (Herrington \& Kew 2016). If this phenomenon continues, there will be no future for our communities and the country at large. So something has to be done quickly and wisely. The people will continue relying on grants from the government.

In its quarterly Labour Force Survey for January to March 2016, Statistics South Africa announced that 5.2 million people, or $26.7 \%$ of the population, were unemployed (Manyaka-Boshielo 2017). Perhaps if the churches would become more proactive and critically look into this crisis, they might find a solution. A possible solution to this severe national crisis could be social entrepreneurship.

In this study, the researcher investigated if there was a positive response to this unemployment problem by the churches that operate in Mamelodi East and the inner city of Pretoria? Also, how can the church become involved in social entrepreneurship? Next, the researcher explored the social entrepreneurship concept.

\section{What is social entrepreneurship?}

Social entrepreneurship has many definitions from scholars and researchers. It seems as if everyone who is defining it looks at it from his or her own dimension. Dees (1998) described the concept of social entrepreneurship as meaning different things to different people. For some, social entrepreneurship is exclusively concerning a not-for-profit organisation's starting a forprofit venture for earned-income. Others may view it to describe anyone who starts a not-forprofit organisation. And some use it to refer to business owners who integrate social responsibility into the operation. The researcher's personal understanding is that the focus of 'social' is on

Note: This article forms part of a collaborative research project entitled 'Religious innovation and competition amidst urban social change: a Pretoria case study'. The project was funded by the Templeton Foundation as part of an African-wide enquiry on 'Christianity and social change in contemporary Africa'.

The project is also a sub-theme of the 'Faith in the City' research project, hosted by the Centre for Contextual Ministry in the Faculty of Theology, University of Pretoria. 
addressing social concerns, while the 'entrepreneur' component is more geared towards generating profit or creating wealth. And this profit will be used for making advances in creating social value. Simply, it means that the social entrepreneur will never only depend on government or donors. In this research, the researcher shall define social entrepreneurship as follows.

Austin, Stevenson and Wei-Skillern (2006:2) highlighted that social entrepreneurship is an innovative 'social value-creating activity that can occur within or across the non-profit, business, or government sectors' (Manyaka-Boshielo 2017).

Manyaka (2015:7) and Manyaka-Boshielo (2017) defined social entrepreneurship across three phases:

1. identifying a stable but inherently unjust equilibrium that causes the exclusion, marginalisation or suffering of a segment of humanity that lacks the financial means or political clout to achieve any transformative benefits on its own;

2. identifying an opportunity in this unjust equilibrium, developing a social value proposition and bringing to bear inspiration, creativity, direct action, courage and fortitude, thereby challenging the stable state's harmony; and

3. forging a new, stable equilibrium that releases trapped potential or alleviates the suffering of the targeted group, and through imitation and the creation of a stable ecosystem around the new equilibrium, ensuring a better future for the targeted group or even society at large.

Social entrepreneurship is a process involving the innovative use and combination of resources to purpose opportunities to catalyse social change and or address social needs (Mair \& Marti 2006:37). Bacq and Janssen (2011:388) define social entrepreneurship as the process of identifying, evaluating and exploiting opportunities aiming at social value creation by means of commercial, market-based activities and of the use of a wide range of resources.

Social entrepreneurship is a processual perspective that extends entrepreneurship beyond the creation of wealth to include action that brings about new economic, social, institutional and cultural environment (Haugh \& Talwar 2016:644). Social entrepreneurs use creative and innovative means to create wealth that he or she may adventure in a comprehensive social transformation.

The researcher describes social entrepreneurship as a game changer, which disrupts harmony or the status quo. It is a process of transforming not only the economic environment but likes to transform social conditions. People are being freed from every oppression or limitation to act as free human beings.

\section{Social entrepreneurship and social change}

There is a strong link between social entrepreneurship and social change. In the description of social entrepreneurship given above, it is a process of identifying a stable inherently unjust equilibrium that causes exclusion and marginalisation. This marginalisation is disempowering for the people who live in this kind of context. A social entrepreneurship process is a way of identifying opportunity in an unjust equilibrium and manages to come up with social value creation strategies that can help people to be aware of their autonomy and freedom to make change.

Entrepreneurship orientates the focus of entrepreneurial activity towards the pursuit of freedom and autonomy relative to an existing position (Haugh \& Talwar 2016; Rindova, Barry \& Ketchen 2009). The grant of narrative of emancipation is also concerned with hopeful aspirations of autonomy, breaking free from the power of another and, by breaking free from existing social order, is inherently linked with disrupting the status quo (Haugh \& Talwar 2016). Social entrepreneurs are social changers.

\section{Missional Church}

From the beginning God had a bigger plan, which was Salvation for humanity, his created people. As Jurgen Moltmann said, 'it is not the church that has a mission of Salvation to fulfil in the world; it is the mission of the Son and the Spirit through the father that includes the Church' (Woodward 2012:28). His mission was to create peace (Shalom) or harmony in his entire creation (Manyaka 2010:134). In Genesis 1:1 (NIV) it says, 'in the beginning God created heaven and earth. The earth was furnished with all types of animals and plants. And God blessed the creation' (1:22):

then God said, let us make mankind in our image, in our likeness, so that they may rule over the fish in the sea and the birds in the sky, over livestock all the wild animals and over all creatures that move along the ground. (Gn 1:26 NIV)

Being made in the image of God could mean four things: a spiritual being capable of immortality, a moral being, being God's likeness and an intellectual being with the capacity for reason and ruler. Being and having the image of God, it means representation of God on the earth or land (Manyaka 2010).

We find missio Dei in Scripture: God the father sends the Son and the Spirit into the world, and God the father, Son and Spirit send the church into the world for the sake of the world (Woodward 2012:27). So there is a strong connection between missio Dei and the Trinity. God sent his Son into the broken world to redeem it from a fall, the Son sent the Holy Spirit to empower the church so that it could be effective in its work of mission and the Holy Spirit sent the church into the world.

Missional ecclesiology is not so much a study of the church, concerning its size, number, the efficiency of church programmes and projects, but more on focusing on the conceptual, communal, missional transformation of the triune God in seeking its identity and calling (Choi 2017:60). This missio Dei is centred on the cross of Jesus, resolves any dualisms, the tension and conflict between body and soul, evangelism and social action (Choi 2017:60). The missio Dei is 
always a holistic dimension of the gospel. It affects spiritual, mental, physical, social, and political and economics.

The mission of church derived from the mission of God. Jesus Christ gave his church this mission: Matthew 28:19 says, 'therefore go and make disciples of all nations, baptising them in the name of the father, and of the Son and of the Holy Spirit'. The definition of a missional church as the essential nature and vocation of the church as God called and sent people (Fagerli et al. 2012:16).

Van Huysteen (2006:120) and Towner (2001:26) have stated that humans are walking representations of God, and as such are of exquisite value and importance. Humans are taking care of what God has created and what He values so much (Manyaka 2010:15). The researcher put creation into this article because he believes that the mission of God started from creation. Man was created to fulfil this mission, but sin disturbed that mission for humankind. Hence, in next section the researcher will look into the responsibility of humankind.

\section{Responsibility of mankind}

Mankind was given dominion over the creation of God. Towner (2001:28) explained that dominion in this way is stewardship, nurture and responsibility towards the things God loves. Manyaka (2010:15) put it this way, 'you have made him to have dominion over the work of God'. Genesis 2:15 says, 'The lord God took man and put him in the Garden of Eden to work it and take care of it'. Man is at the centre of God's creation.

The other reality here is the issue of the land or the earth. God had created the earth to produce for mankind. Genesis 2:9 says, 'the Lord God made all kinds of trees that were pleasing to the eyes and good for food'. Also, we see in Deuteronomy 8:10, God saying, 'when you have eaten and are satisfied praise the Lord your God for the good land he has given you'.

The Lord God gave land, the land gives food to mankind and mankind has to praise God. The land has been a critical reality in God's creation for many centuries and is still a critical reality today, in South Africa. Today, South Africans still cry for landlessness. And it is true that without the land you cannot experience the blessings of God fully. There should be healthy relations between mankind, land and God. It is true that if this harmony or shalom is not in place, the mission of God for his creation is lost. What broke the harmony in God's creation? Sin broke the harmony in God's creation. Jesus Christ was sent to bring back that harmony in his creation, by demolishing the power of Satan.

What is sin? It is very important to understand the meaning of the concept of sin. According to Grenz (1994:237) who stated the nature of sin following the Hebrew words as follows: avah [bent or crooked], aval [lack of integrity], avar [to cross over or transgress], $r a$ [the rule of evil], ma al [breach of trust], Pasha [to revolt or refuse subjection to authority] and chatta [to miss the right point or to deviate from the norm].

Also, Grenz (1994:137) continues giving the meaning of sin, using the Greek words: parabasis [the transgression of a boundary], parkoe [disobedience to a voice], paraptoma [falling where one should have stood upright], agnoema [ignorance of what one should have known], hettama [the diminishing of what should have been fully rendered] and plemmeleia [a discord in harmony in God's universe] (Manyaka 2010).

Paul has this to say concerning God's mission, Ephesians $1: 10$, 'to put into effect when the times reach their fulfilmentto bring unity in heaven and on earth under Christ'. Paul continues saying God is reconciling the world to himself through Christ (2 Cor 5:19). When we read the scriptures, we learn that it is God's mission to set things right in a broken and messed-up world (Woodward 2012:28); he continues saying God's mission is to redeem the world and restore it for its intended purpose.

Carlson (2007) defined the missional church as an authentic community of faith that primarily directs its ministry focus outwards towards the context in which it is located and to the broader world beyond.

The goal of God's mission becomes the humanisation or (shalom) of the society through the efforts of Christians in cooperation with other social institutions aimed at the transformation of oppressive political, social and economic structures

The message of Salvation is the message of integral human liberation and progress. For this reason, the first task of the church in the city is to help people to better their quality of material as well as their social livelihood (Moloi 2014:5).

Salvation in cities underlines humanity and enhances positive human values of urban life. These are the values that enable human beings to transcend the human condition and to live the true life that is hidden with Christ in God (Moloi 2014:5).

The mission of God in townships is to help those marginalised to rise above the limitations that were put on their lives. The mission of God is to help the people who are excluded to enable them to use innovation so that they will be able to see the possibilities of how to free themselves.

The term church derived from the Greek (Gk) word ekklesia, meaning the called out ones. It simply means that the church consists of people who are called to be the house of God in the world. The church is the temple of God; it is where God dwells. The church belongs to Christ. We can read in the Bible that he will build his church, and the kingdom of Satan cannot prevail against her. 


\section{The social entrepreneurial Church or Churchpreneur}

God's invitation to us is to be co-labourers in this endeavour, to bring about sustainable change through pattern-breaking ideas that will require all the creativity of the Holy Spirit-empowered entrepreneurs (Mostert 2012). Social entrepreneurs are God's representatives, partnering with God for social change or social transformation. The researcher proposes that social and business entrepreneurship should or is part and parcel of the missio Dei. Theologically, we might differ. Church leaders are not yet sure-footed nor united theologically in justifying social concern as part of the church's mission (Samuel \& Snugden 1999:47).

What is Churchpreneur? This is the church that adds to her spiritual function of preaching and teaching the word entrepreneurial activities in the church and the context in which Churchpreneur operate. It is not just following the old way of doing things. This means charting new paradigms and creating strategies to move forward (Hirsch \& Catchim 2012). This kind of church draws new maps to chart the future; old maps could be learned from but cannot be trusted to take us into the new future. Social entrepreneurship is what the church should promote today, rather than promising manna from heaven that will never come.

Social entrepreneurs should face every challenge with what Buddhists call a 'beginner's mind' - 'a way of thinking that is open, alert, and free of dogma' (Bornstein \& Davis 2010:77).

\section{Three essential components of the Churchpreneur}

Just like any organisation, Churchpreneur must be sustainable in order to be an agent of transformation. The following three are essential components, as they have been indicated by Allan Hirsch and Tim Catchim (2012:167).

\section{The right idea}

This refers to the DNA being the core or foundational of the thing or organisation. Coming to the Churchpreneur, this would address a correct theology, ecclesiology (what) and strategy (how).

\section{The right people}

If one has a good idea or theology but has bad people his or her vision cannot proceed. Churchpreneur needs people with a positive attitude, the correct skills, committed to work hard and some experience for the job one is in.

\section{The right resource}

This will go beyond funding. It needs the faithful in taking care of everything that God has blessed us with. We must be able to attract and be good stewards of the resources God has given to his children.
According to the researcher, the church cannot afford to only give people food parcels, but it must lead the members into a comprehensive or holistic Salvation. The church must teach communities how to catch fish rather than to give them fish when they are hungry. If the church is to continue giving food parcels forever, she destroys the intention of God that everyone must have the true freedom of self-support. Food parcels should be made temporal not permanent.

Paul Francis exhorts, especially the Roman Catholic Church, to say, [n] to economy of exclusion, no to the idolatry of money, no to a financial system which rules rather than serves and no to the inequality which spawns violence (Mangayi 2014:5).

Therefore, a missional church is a Churchpreneur, is in the world to add value to society through creative and innovative ways. It is empowering the communities to rise against social limitations and constraints in the communities. A missional church or Churchpreneur is to ignite the potential in the lives of those who have been affected by limitation. Then limitation shall be broken and people shall live their lives happily.

The church as a society created by the Holy Spirit continues to participate in God's ongoing creative activities (Choi 2017). An innovative and creative way is the gift of the Holy Spirit. When congregants are engaging in social entrepreneurship they are practising their call from God. The Bible says in Exodus 31:3 (NIV), 'and I have filled him with the spirit of God, with wisdom, with understanding, with knowledge and with all kinds of skills'. In communities, there are people who are called and being sent by God into the world to engage in social entrepreneurship so that the work of God, recreating the earth, is taking place. Looking at the above section on Churchpreneur, they can play a significant role in fighting poverty and the next section will investigate some case studies on Churchpreneur.

\section{Case studies on social entrepreneurship and the Church Korea Church in Los Angeles}

Korean churches in Los Angeles are truly spiritual social entrepreneurship in their community. They are amongst some of the churches that we can learn from. Choi (2010) puts it this way: Korean churches are involved with business and community development issues directly and indirectly. Some churches and pastors hold formal programmes to inform their members of business opportunities. The churches are acting as incubators for small businesses that belong to the Koreans. Also, churches have started a formal and informal organisation that could afford to offer loans to the Koreans because the conventional banks are unable to offer Koreans loans. So the churches in the inner city of Pretoria and Mamelodi East could learn from the Koreans how they have supported the businesses of their members. These Koreans were excluded by the system because they were foreign nationals. Black South Africans though they belong to this country, because of apartheid, they were excluded from the 
main stream of the economy. The banks are hesitant to offer loans to black South Africans. Apart from being excluded from the economy, black South Africans generally lack business skills because of this exclusion.

Oham (2015) in his report mentioned four examples of faithbased outcomes of his explorative research. They are as follows.

\section{Community centre project}

A community centre project will house the church, a community centre and a hub for social enterprises in a suburb of Oxford. The key strands of this project will be to improve mental health in the community, run community development projects, improve educational objectives and support refugees in a deprived area of Oxford. The proposed centre will address the critical needs of a highly deprived area in Oxford affected by high levels of unemployment and poverty. The project will be run as a social enterprise; this should sustain the activities of the whole community.

\section{Church-led social enterprise café}

Church-led social enterprise café is a community café initiated and run by group of churches in a major new housing development in East London. The property developers and the local authority as part of their social cause set up a community development trust bequeathed with an endowment fund. The trust activities will be funded by the interest generated from the endowment and rents from level shop units and a community hall. The parish vicar and estate chaplain proposed using one of the trust's shop units as a café. The vicar and estate chaplain were able to convince the board to give the Church of England parish one of the units to run as a café on behalf of the community and the local churches. The idea was for the churches to demonstrate their commitment to the community by social action.

\section{Church community centre}

Church community centre is a community run by the local church for the community. The church had a declining and elderly congregation coupled with high overheads for maintaining an old building. As a result of this situation, the board sold some of their land and the church hall and reinvested the funds in modernising the church building. It included replacing the pews and movable chairs, thereby turning the church into a multipurpose hall for the community. The multipurpose hall is hired out for a number of community activities each week except on Sundays when it is used for worship.

Weekly activities include a dance class that trains over 50 students a week, several scout groups (clubs, beavers and guides), yoga and exercise classes, several lunch classes, parents and toddlers classes.

This trading activity using existing resources has led to an increase in income and the sustainability of the churches' primary objective (being a worship centre).

\section{Christian social entrepreneurship}

A Christian social entrepreneurship is a social enterprise that provides a range of services to the local community, services which include housing, clothes, recycling, charity shops and cafes. All the profits generated by the social enterprise chains are ploughed back to fulfil the objectives of the social enterprise which is for the advancement of the Christian faith through teaching and releasing people's skills for work, the advancement of education and the relief of poverty in needy circumstances.

The Christian social enterprise is not directly attached to any church; it has a team of practising Christians and ministers of religion that are members of a board or work for the social enterprise in some capacity. The organisation actively works with local churches in the area.

\section{Economic activities in City of Tshwane}

The City of Tshwane contributes $27.0 \%$ of Gauteng Province's GDP (stands for gross domestic product) and $9.0 \%$ of the National GDP (Ramokgopa 2016). Its economy is vibrant and diverse.

The population of City of Tshwane has been estimated at $2921488,71.9 \%$ of the population being of working age (15-64). The unemployment rate is $24.2 \%$, the youth unemployment rate stands at $32.6 \%$ and the dependency rate is 39.0\% of the population (Mangayi 2014:2). With these statistics the people of the City of Tshwane will experience harsh realities such as crime and fear of crime in their daily living. They will not be able to get what is best in life. It will exacerbate socio-economic and exclusion.

\section{Methodological considerations}

In pursued of participation in knowledge generation:

transdisciplinary approach starts with the issue or problem and through the process of problem solving, bring to bear the knowledge of those disciplines that contribute to the solution or resolution. (Kaufman et al. 2003:6)

Aenis (2010) described trans-disciplinary as a research process crossing the boundaries between scientifically trained individuals and non-scientists.

\section{Participatory or collaborative discovery and construction of knowledge}

Reason and Bradbury (2001) speak of action research as:

a participatory democratic process concerned with developing practical knowing in the pursuit of worthwhile human purposes, grounded in a participatory worldview which we believe is emerging at this historical moment. (p. 1)

\section{Methods}

The methods we shall use in this research project must empower the co-researchers and help them to realise their 
agency or their full potential. The researcher shall combine literature study and conceptual analysis, with mapping, surveys, focus groups and a number of world cafes.

\section{Mapping}

Researchers mapped both the inner city of Pretoria and Mamelodi East and $1 \mathrm{~km}$ around the University of Pretoria Mamelodi Campus. This mapping method helped us to unearth the church that was hidden from many of the people who do not stay in Mamelodi because other churches operate in an open space by pitching a tent only on Sundays, and after the Sunday service the tent would be removed.

\section{Survey}

The survey forms were defined as a tool to gather information about the churches in the region under the research project. Only the leaders of the churches were requested to fill the form. Many pastors found it difficult to fill the form. Some even refused to complete it. The reason for this difficulty is not known to us this far. It might be, because of the informality of some of the churches, certain information was kept from researchers. We also had a real sense that some other churches were hesitant to participate because of the rather newly formed commission for the promotion and protection of the rights of cultural, religious and linguistic communities (Act of 2002) (CRL Commission), set up as an independent chapter nine institution, in terms of the South African Constitution.

\section{Focus group}

From the mapping and surveys, we selected six groups per region (12 in total) for more in-depth engagement through focus groups and unstructured interviews. For this article, phenomena of social entrepreneurship were explored as a means to respond to unemployment in the two regions focused in this research.

\section{World Café}

We decided to include a method used in open space technology, known as the World Café, as one of the methods in our research process, particularly emphasising our desire to construct understanding and insight on local contexts together. The World Café is:

A simple yet powerful conversational process that helps groups of all sizes to engage in constructive dialogue, to build personal relationships, and to foster collaborative learning. (Tan and Brown 2005)

\section{Findings of research}

Even though the concept of social entrepreneurship was very new amongst the church leaders, when we were discussing, there was not much knowledge on the matter. Fortunately there were patterns that could be related to the concept of social entrepreneurship. These churches were practising social entrepreneurship as explained in this article.

\section{Pre-school or crèche}

As much as $80 \%$ of the church, especially those who had a permanent building or are renting buildings, are running the pre-schools or crèches. Leaders confirm this even though the aim or purpose of this ministry is to empower the children, on the other hand this is also a money-making business so that the work of the ministry might continue. Also, this is a job creation project for church members who are unemployed. This project, if it is well run according to the norm and standards of the government, has the potential of attracting resources from the government and other donors.

\section{Teaching art to the young people}

One pastor in Mamelodi East who conducts church services in his yard makes money through art work. He draws billboards and other advertising tools. The money he earned from this business supports his family and his church. He responds to unemployment in his community through training the youth of his community in art drawing. He knows once children have skills they can support themselves and their family. Indeed this pastor is a social entrepreneur even though he does not call himself a social entrepreneur.

\section{Empowerment workshop}

Golden gate had a rather pronounced vision of transforming the way things are being carried out: they spoke of being and creating social business; instead of church leaders promoting materialism, leaders being greedy or waiting for God to act, they wanted to stand in the gap to address the lack of resources, vision and so forth. In order to do so they started amongst other things an education desk, a sports desk, business seminars and empowerment seminars for people in their community.

\section{Start-up donation}

The other churches in the city contribute money so that they might help those who would wish to start a small business. It starts by training the members on how to start and manage a small business. And the members who have started and are working as a manager, wherever they work are encouraged to recruit from unemployed members of the church.

\section{Recommendation}

As we have seen in the inner city of Pretoria and Mamelodi East, social entrepreneurship has taken place in these areas. The churches have the ability to fight poverty through engaging in social entrepreneurship activities. The church leaders can change their environment through promoting and encouraging their members to be more active in social entrepreneurship activities.

The theological institutes should consider including social entrepreneurship to their curriculum so that they can empower church leaders for their future work. And further theological institutions should carry out much more research regarding social entrepreneurship and church. 


\section{Conclusion}

Manyaka (2015) argues that in this way, I see social entrepreneurship acting as a steward for the works of His hands' and helping to co-create a better community. Social entrepreneurs are adding value to society through innovative and creative action

As discussed by the researcher, poverty as one of the major problems in the inner city of Pretoria and Mamelodi East, so churches are in a position to fight poverty and improve the living conditions of these two areas through promoting social entrepreneurship activities. Members of the church should understand that they are co-workers with God, and cocreating a better community is what God called them to.

\section{Acknowledgements Competing interests}

The author declares that he has no financial or personal relationships which may have inappropriately influenced him in writing this article.

\section{References}

Aenis, T., 2010, A communication model for transdisciplinary consortium research, A conference paper presented on the 9th European IFSA Symposium, Vienna, Austria.

Austin, J., Stevenson, H. \& Wei-Skillern, J., 2006, 'Social and commercial entrepreneurship: Same, different or both?', Entrepreneurship Theory and Practice 30(1), 1-22. https://doi.org/10.1111/j.1540-6520.2006.00107.x

Bacq, S. \& Janssen, F., 2011, 'The multiple faces of social entrepreneurship: A review of definitional issues on geographical and thematic criteria', Entrepreneurship and Regional Development 23, 373-403. https://doi.org/10.1080/08985626.2011.577242

Bornstein, D. \& Davis, S., 2010, Social entrepreneurship: What everyone needs to know? Oxford University Press, Madison, WI.

Carlson, R., 2007, Definition of a Missional Church, Missional Church Strategist for National Ministries, ABCUSA, US.

Choi, H., 2010, 'Institutions and ethnic entrepreneurship: The Korean Ethnic Church as an incubator of economic', Development Quarterly 24(4), 372-382. https://doi. org/10.1177/0891242410375426

Choi, H.K., 2017, 'Missional conversion and transformation in the context of the Korean Protestant Church', Mission Studies 34, 53-77. https://doi. org/10.1163/15733831-12341483

Dees, J.G., 1998, The Meaning of 'Social Entrepreneurship', Stanford University: Draft Report for the Kauffman Center for Entrepreneurial Leadership, viewed 31 Octobe 2013, from http://community-wealth.org/sites/clone.community-wealth.org/files/ downloads/paper-dees.pdf
Fagerli, B., Jorgensen, K., Olsen, R., Haug, K.S. \& Tveitereid, K., 2012, A learning Missional Church: Reflections from young missiologists, Regnum Books International, Oxford.

Grenz, S.J., 1994, Theology for the community of God, Paternoster Press, Carlie.

Haugh, H.M. \& Talwar, A., 2016, 'Linking social entrepreneurship and social change: The mediating role of empowerment', Journal of Business Ethics 133, 643-658. https://doi.org/10.1007s10551-014-2449-4

Herrington, M. \& Kew, P., 2016, South African report 2015/16. Is South Africa heading for economic meltdown? Global Enterprise minitor, viewed 21 June 2016, from http://www.gemconsortium,org/report/49537

Hirsch, A. \& Catichim, T., 2012, The permanent revolution: Apostolic imagination and practice for the 21st century church, Jossey-Bass, San Francisco, CA

Holy Bible, 2011, Holy Bible, New International Version, Zondervan, US.

Kaufman, G., Moss, D.M. \& Osborn, 2003. Beyond the boundaries: A transdisciplinary approach to learning and training, Greenwood Publishing Group, Inc., US.

Mair, J. \& Mart, I., 2006, 'Social entrepreneurship research: A source of explanation, prediction, and delight', Journal of World Business 41, 36-44. https://doi. org/10.1016/j.jwb.2005.09.002

Mangayi, L.C., 2014, 'Mission as local economy development in the City of Tshwane: Towards fostering a grass roots, 'glocal' alternative vision, with specific reference to Luke 16:19-31', HTS Teologiese Studie/Theological Studies 70(3), art \#2744, 1-9. https://doi.org/10.4102/hts.v70i2744

Manyaka, S.J., 2010, 'The marginalized stories of people who live in poverty: A pastoral narrative approach to community transformational development', Unpublished thesis, University of Pretoria.

Manyaka, S.J., 2015, 'Social entrepreneurship: A solution for transforming the disadvantaged community of Nellmapius', HTS Teologiese Studies/Theological Studies 71(3), 7. https://doi.org/10.4102/hts.v71i3.2821

Manyaka-Boshielo, S.J., 2017, Social entrepreneurship as a way of developing sustainable township economies, Unpublished.

Moloi, V., 2014, 'Living in townships: An appraisal of Pentecostal social ministry in Tshwane' HTS Theologies Studies/Theological Studies 70(3), art \#2791, 1-9. https://doi.org/10.4102/hts.v70i3.2791

Mostert, J., 2012, 'Community psychology as socio-missional-entrepreneurship', Journal of Psychology and Christianity 3(1), 66-67.

Oham, C., 2015, Faith-Based social enterprise capacity building study, Oxford University innovation Partnership study programme, Oxford.

Ramokgopa, K., 2016, 'Tshwane's economy performing better than rest of SA', Fin24.com. 2016

Reason, P. \& Bradbury, H., 2001, Handbook of action research: Participative enquiry and practice, Sage, London.

Rindova, D., Barry, D. \& Ketchen, D.J., 2009, 'Entrepreneurship as emancipation', Academy of Management Review 34(30), 477-491. https://doi.org/10.5465/ AMR.2009.40632647

Samuel, V. \& Snugden, C., 1999, Mission as transformation. A theology of the whole gospel, Regnum publishers, Oxford.

Tan, S. \& Brown, J., 2005, 'The world café in Singapore, creating a culture through dialogue', Journal of Applied Behavioural Science 41, 83-90.

Towner, W.S., 2001, Genesis, Westminster John Knox, Louisville, KY.

Van Huysteen, W., 2006, Alone in the World? Human uniqueness in Science and Theology, William B. Eerdmans Pub, Grand Rapids, MI.

Woodward, J.R., 2012, Creating a missional culture: Equipping the church for the sake of the world, IVP Press, Madison, WI. 